\title{
Predictive factors to avoid farming as a livelihood
}

\author{
H. M. Vinaya Kumar* ${ }^{*}$, N. B. Chauhan, D. D. Patel and J. B. Patel
}

*Correspondence:

vinayhm11@gmail.com;

vinay@aau.in

Department

of Agricultural Extension

and Communication, Anand

Agricultural University,

Anand, Anand 388110, India

\begin{abstract}
Farming in India is experiencing a structural change leading to a crisis. The growth rate of agricultural output is steadily declining in recent years. The relative contribution of the farming sector to the total GDP has been decreasing over time increasingly. The present study was conducted in Ahmedabad district of Gujarat, India. Total 100 agricultural landholders from 20 villages were selected to identify factors experienced by them for avoiding farming as a livelihood by employing Ex-Post-Facto research design. It is observed that ' $r$ ' computed between factors to avoid agriculture as a livelihood and age (0.589), education (0.330), farming experience (0.250), occupation (0.446), livestock possession (0.207), annual income ( -0.236 ) was found to be significant at 0.01 level of significance. It could be observed from regression analysis that the personal factors had a powerful effect (0.730) on avoiding agriculture as a profession, influencing in a positive direction. Followed by this, economic factor (0.291) and social factor (0.229) also influenced positively and significantly. The information on the personal, social, economic, psychological, market, situational, labor and next-generation factors experienced by agricultural landholders is analyzed to have in-depth knowledge of each factor. The analyzed suggestions will help to make agriculture a profitable enterprise and attract the farmers and youths to continue the farming activities. The solution to the problem is not in a few packages and programs but in drastic changes in the present policies related to agriculture need to be focused. Other sector's growth and development must not be at the cost of agriculture.
\end{abstract}

Keywords: Agriculture, Crisis, Farmers, Factors, Livelihood, Sustainability

\section{Introduction}

Farming plays a significant role in the Indian economy. Over $53 \%$ of the rural households depend on agriculture as their chief means of livelihood with $52 \%$ share in employment. India has blessed with all the things, which are required for the development of the country, like the availability of needed precipitation, most significant human resource, diversifies biodiversity and the year around market demand. However, the share of agriculture to the GDP in 1951 was around 54\%, which was less than 16\% in 2017-2018. During the globalization period around 1991-1992, on a perception of increasing productivity, farmers followed the indiscriminate application of an enormous quantity of fertilizers, chemicals, overexploitation of groundwater and natural resources was observed. Due to this, the input cost has been increasing day by day and farming has become unrewarding over the years. Because of this, the farm income is increasingly declining, so the majority

(c) The Author(s) 2019. This article is distributed under the terms of the Creative Commons Attribution 4.0 International License (http://creativecommons.org/licenses/by/4.0/), which permits unrestricted use, distribution, and reproduction in any medium, provided you give appropriate credit to the original author(s) and the source, provide a link to the Creative Commons license, and indicate if changes were made. 
of farmers want to quit agriculture if given an alternate choice. There are nearly 15 million farmers less than there were in 1991 and over 7.7 million farmers less since 2001. On an average, that is about 2035 agrarians losing 'Key Cultivator' status every single day for the last 20 years. There are 95.8 million farmers for whom farming is their principal occupation. That is less than $8 \%$ of the population (Down from 103 million in 2001 and 110 million in 1991). Include all marginal farmers (22.8 million), and that is still less than $10 \%$ of the population (Agriculture Census 2011) . Even all cultivators and agricultural laborers count together; the number would be around 263 million or $22 \%$ of the population (Sainath 2013). It is anticipated that by 2035 , roughly $50 \%$ of India's population will be urban-based from agricultural to non-agricultural occupation will create a food security concern in India (FAO 2012, 2014b).

In the early 1990s, farming in India, particularly in rural India, has declined at a shocking rate. This had a distressing impact on the livelihood of farm families. Symptoms of this farming crisis, unprecedented in Post-Independent India, are an increased rate of suicides among agrarians (Parthasarathy and Shameem 1998; Vyas 2004). The droughthit state, Maharashtra, reported 852 agrarians suicides in the first 4 months of 2017, while in 2015, one of the disaster years on record, about 12,602 farmers committed suicides in India (Table 1). There is an indication that, globally, farming is an occupation with a greater risk for suicide than other professions (Citizens' Report 1998; Milner et al. 2013; Agerbo et al. 2007). Rural India and its unprecedented financial crisis, as per the 2011 Census of India urban India added further to its population than rural India. This implies that millions of people previously engaged in farming are migrating in search of jobs and daily wages in cities. Another evidence for a significant farming crisis in India is the very high rate in which people are leaving farming. Agriculture in India had in height growth for a long time up the too late 1980s and early 1990s. After that it slowed down due to overexploitation of technology closer to the possible limits, which led to increasing input and production costs, shrinking resource base, declining production, productivity, profitability and incomes (Gill and Lakhwinder 2006; Singh 2009). The Indian farmers especially the marginal and small farmers also had little alternative to go for capital-intensive farming. The overexploitation of natural resources especially groundwater, intensive chemical, poor quality of soil, and fertilizer application, further

Table 1 Farmers suicide hot spots during the year 2015. Source: Accidental deaths and Suicides in India (2015), National Crime Records Bureau

\begin{tabular}{llcc}
\hline SI. no. & State & No. of suicides & \% share in total \\
\hline 1. & Maharashtra & 4291 & 34.1 \\
2. & Karnataka & 1569 & 12.5 \\
3. & Telangana & 1400 & 11.1 \\
4. & Madhya Pradesh & 1290 & 10.2 \\
5. & Chhattisgarh & 954 & 7.6 \\
6. & Andhra Pradesh & 916 & 7.3 \\
7. & Tamil Nadu & 606 & 4.8 \\
8. & Total (Seven states) & 11,026 & 87.5 \\
9. & Total No. of farmers suicides in & 12,602 & \\
\hline
\end{tabular}

Total number of suicides by farmers in $2015(12,602)$ is $2 \%$ higher than $2014(12,360)$; Maharashtra reported 852 agrarians suicides in the first 4 months of 2017 
pulled the farm incomes toward tunneling deeper for submersible pumps installation (Singh 2008). During the era of high growth (1969-1990), the farmers attained high living standards, which also led to their social and cultural liabilities being more luxurious but, what is their present (2000 onwards) situation? Indebtedness of the farmers, more so to the non-institutional interventions and particularly of the small and marginal farmers, whose economic base is more miserable, enlarged faster than their repaying capacity. As an effect, their distress continued to mount. The indebtedness of the farmers had been a serious issue since long. So, Indian farmers' higher rates may simply fit this pattern and warrant little explanation. However, evidence suggests that a substantial investigation into the causes of this crisis is an imperative, as along with the increasing rates of farmer suicides, research suggests that these suicides are not occurring from more organic processes such as mental health problems, but from socioeconomic and psychosocial circumstances (Singh 2004; Sidhu 2011; Dominic 2017). Numerous reports state that farmers have died by suicide at rates exceeding those of the general population (Vaidyanathan 2006; FAO 2014a; Patel et al. 2012; Nagaraj 2015).

The survey of 5000 farm families across 18 states in India says that $75 \%$ of farmers would desire to do some work other than farming (Krishnan 2015). Sixty-one percent of these agrarians would prefer to be in employment in cities because of better education and continuous income (Krishnaswamy 2015). A high proportion of farmers complained of repeated losses; $70 \%$ of respondents said their crops were damaged because of unseasonal rains, drought, floods, pest and disease outbreaks, etc. (Sood 2014).

Over the last five-six decades, the Maharashtra state has witnessed a successive trend of increase in the number of farmers regarding land division and population growth. But, the number of farmers in the state started to decrease from 2010 to 2011. The amount was 1.37 crore in the Maharashtra state in 2010-2011 but, went down to 1.36 crore by 2013-2014 (Mitra and Shroff 2007). In the course of the same period, the area of operational holding and the average size of operational holding also went down (Deshmukh 2015). Maharashtra witnessed the highest number of agrarian suicides among states of Indian in 2015, with 4291 cases, compared to 1569 in Karnataka, and 1290 in Madhya Pradesh (Table 1). In the present context, farmers take the most significant risk but are the least beneficiaries.

Deprived and populous states like Bihar, Jharkhand, and West Bengal were the worst performers. In West Bengal, 92\% of rural households owned less than one hectare of land. Jharkhand with $86 \%$ and Bihar with $85.3 \%$ exhibited a similar trend. Massive movements of farmers present complex challenges. Rural areas of source risk losing the younger and often most effective share of their workforce (Sarma 2004; Business Standard 2015).

Question regarding farming as a profession are namely of what? (Farming activities to deliver outcomes), to what? (Agriculture stresses and shocks), for whom? (Agrarian actors) and Over what time period? (Short-/long-term interruptions).

With this drop back the present paper is organized into three parts; (1) study the profile of the agricultural landholders who have avoided farming as a livelihood, (2) examine the factors as experienced by agrarian landholders for preventing farming as a livelihood and (3) explore suggestions to motivate agriculture landholders toward agriculture as a profession. 


\section{Materials and methods}

The investigation was conducted purposively in Ahmedabad district $\left(23.03^{\circ} \mathrm{N} 72.58^{\circ} \mathrm{E}\right)$. All talukas of the district and two villages from each taluka were selected randomly. Five agricultural landholders who left the farming from each village were chosen randomly. Thus, 100 agricultural landholders from 20 villages were selected for the investigation by adopting Ex-Post-Facto research design.

Ahmedabad District is surrounded by Mehsana and Gandhinagar districts to the north, Kheda and Anand Districts to the east, the Gulf of Khambhat (Gulf of Cambay), Botad and Bhavnagar districts to the south, and Surendranagar district to the west. Its headquarters is the city of Ahmedabad. The district is characterized by low and erratic rainfall and increased temperature, with low to average productivity in agriculture (Table 2; Fig. 1).

\subsection{Survey of data}

Data was collected in September-November 2017 through personal interviews using the pretested structured schedule to elicit both qualitative and quantitative data on factors persuading farmers to avoid agriculture as a livelihood. The household interview was conducted with the principal decision-maker of the family, especially on personal, social, economic, psychological, market-related, labor-related, situational and next-generation related factors. The primary objective of the study is to analyze how these factors are affecting to avoid agriculture as a livelihood?

\subsection{Data analysis procedure}

The data collected from all the respondents were coded and tabulated. Keeping in view the objectives of the study and amenability, the data were subjected to different statistical measures. The analytical tools used are summarized below.

\subsection{Percentages}

Percentages were used to make the simple comparison of different groups, and it was particularly useful when the sample size of different respondents was uneven.

\subsection{Mean}

Mean a measure of central tendency was used to classify the farmers' groups and also to show the groups positions concerning farmers' group scores and factors. Further, mean was employed to compare the perceived appropriateness and effectiveness to attract youth toward agriculture as a profession.

Table 2 Profile of the Ahmedabad district of Gujarat, India. Source: District report 2017

\begin{tabular}{llll}
\hline Total geographical area & $8107 \mathrm{~km}^{2}$ (3130 sq mi) & Net sown area (000 ha) & 499.0 \\
Total population & 7059,056 & Avg. temperature & $45^{\circ} \mathrm{C}$ Max and $9{ }^{\circ} \mathrm{C}$ Min \\
Population density & $870 / \mathrm{km}^{2}(2300 / \mathrm{sq}$ mi) & Avg. rainfall $(\mathrm{mm})$ & $756 \mathrm{~mm}$ \\
Sex ratio (Per 1000) & 904 & Soil type & Black, medium black, \\
& & & $\begin{array}{l}\text { and sandy loam } \\
\text { Average literacy }\end{array}$ \\
\hline
\end{tabular}




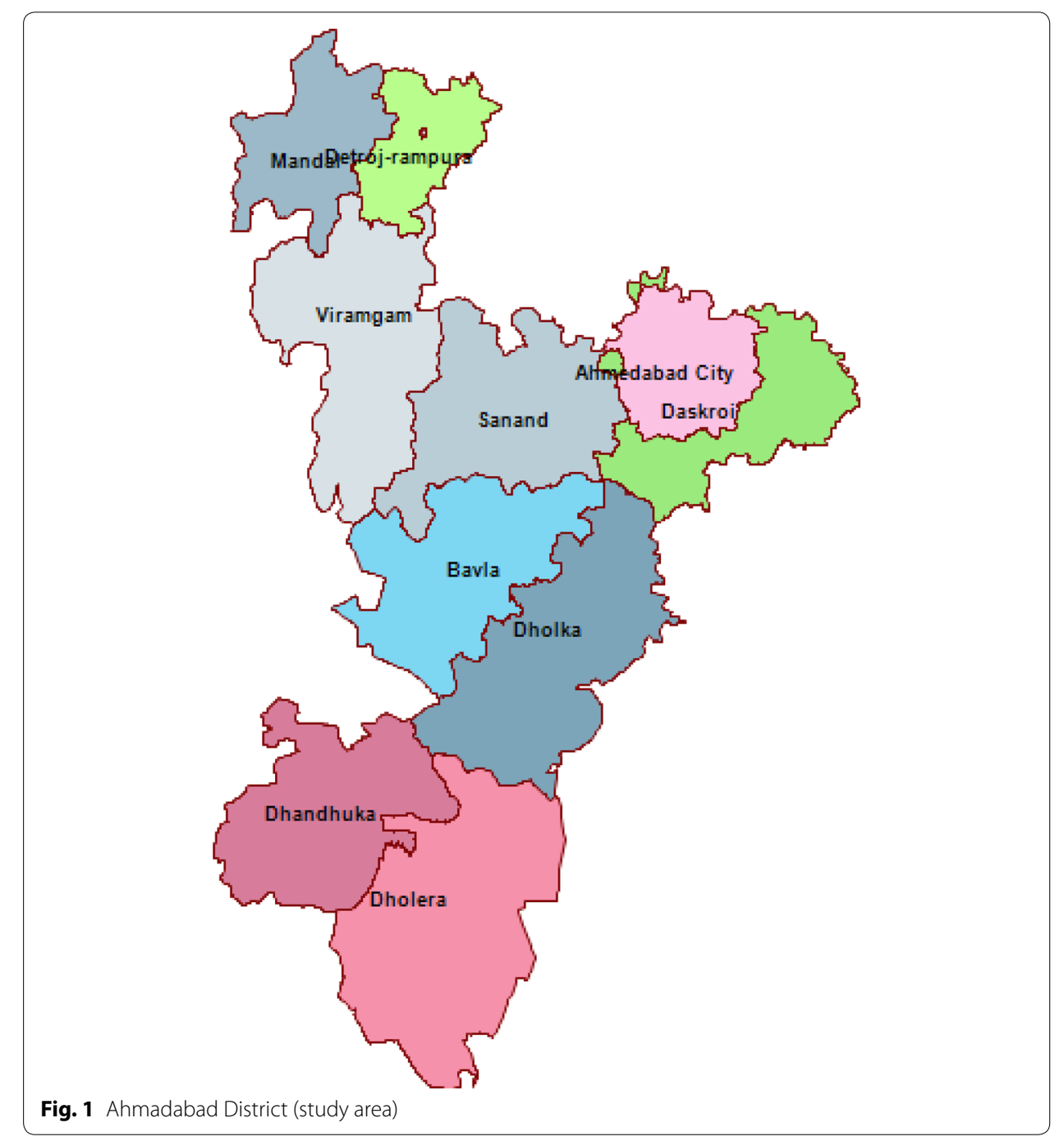

\subsection{Pearson product moment correlation}

The relationship between an independent and dependent variable as well as the reliability of the schedule was confirmed by computing Pearson product moment correlation.

\subsection{Principle component analysis}

Principle component analysis was used to identify the factor or groups of factors contributing to avoid farming as a profession. This analysis was employed to avoid subjectivity and other problems associated with specific activities in conventional analysis such as regression.

\subsection{Stepwise regression analysis}

Stepwise regression analysis was carried out to establish the influence of some of the exogenous variables on avoiding farming as a profession. The stepwise regression analysis was primarily used, so that specification bias of the model does not occur. This selects the best subset of variables in such a manner that (a) it yields the most substantial multiple 
correlations among all subgroups of size ' $\mathrm{n}$ ', (b) the inclusion of remaining $\mathrm{p}^{-\mathrm{m}}$ variables does not significantly improve the prediction of dependent variables.

\section{Results and discussion}

\subsection{Socioeconomic profile of the respondents}

Data presented in Table 3 revealed the complete profile of all the respondents from the entire study area comprising of different personal and socioeconomic characteristics. It is evident from the table that $47 \%$ of the respondents were old aged category followed by middle (34\%) and young (19\%). Regarding educational level, the majority of the respondents belongs to higher-secondary education category (30\%) followed by secondary (28\%) primary $(22 \%)$ and degree and above (20\%) level of education. Very high (86\%) percent of respondents belongs to the high level of farming experience followed by low (7\%) medium (5\%) and very low (2\%) level of farming experience. Equal (31\%) percent of the respondents left the farming since 4-6 years and 7-9 years, respectively, followed by meager (21\%) and high (17\%). About $52 \%$ of respondents belong to medium size family with $5-8$ members followed by $31 \%$ of respondents had small family size with up to 4 members and $17 \%$ of respondents belong to the large family size with equal and more than nine members. Nearly $55 \%$ of respondents belong to nuclear family and rest (45\%) of the respondents belongs to joint family. Thirty-seven percent of respondents have up to 3 members of the family are depending on household decision-maker, followed by $32 \%$ with more than six members and 31\% with $4-5$ members are depending on the household head. Nearly two-thirds $(58 \%)$ of respondents were involved in business activities, and $42 \%$ are engaged in service as their profession. From Table 3, we can see that same percent (43\%) of both small and medium farmers and high land holding is only $14 \%$ was observed. Nearly three-fourths $(72 \%)$ of the respondent have low livestock possession followed by equal (14\%) percent of respondents have medium to high livestock possession. With respect to annual income is concerned, two-fifths $(41 \%)$ of the respondent belongs low level of income ( $₹ \leq 100,000)$ followed by $28 \%$ (₹ 100,001-200,000), 13\% (₹ 200,001-300,000), 7\% (₹ 300,001-400,000), only one percent $(₹ 400,001-500,000)$ and $10 \%$ with high annual income groups $(₹ \geq 500,001)$. The majority (85\%) percent of respondents fall in the medium level of social participation group followed by high (9\%) and low (6\%) level of social participation group.

It could be observed that old age groups are having medium (secondary to higher-secondary education) education with handful farming experience having a better perception of the farming as a profession. Human interventions particularly market; increased input cost and climatic factors are made them more challenging to practice agriculture as their livelihood. With different family type, number and dependence ratio may also influence to adopt other than farming as their livelihood as they were receiving insufficient family income from agriculture. It implies that a respondent opts business and service as his occupation; they can quickly diversify the resources to have secured livelihood. The respondent who is participating in different social organizations can perceive the trends of agriculture and another business opportunity more efficiently and try to acquire relevant technologies for better socioeconomic status in society. The study implied that the respondents having a medium and high level of social participation and higher education have a more significant role in avoiding agriculture as a profession. 
Table 3 Personal and socioeconomic characteristics of the agricultural landholders who have avoided farming as a profession $(n=100)$

\begin{tabular}{|c|c|c|c|}
\hline Characters & Category & Frequency & Percent \\
\hline \multirow[t]{3}{*}{ 1. Age (years) } & Young $\leq 25$ & 19 & 19.0 \\
\hline & Middle $26-40$ & 34 & 34.0 \\
\hline & Old $\geq 41$ & 47 & 47.0 \\
\hline \multirow[t]{4}{*}{ 2. Education } & Primary education & 22 & 22.0 \\
\hline & Secondary education & 28 & 28.0 \\
\hline & Higher-Secondary education & 30 & 30.0 \\
\hline & Degree and above & 20 & 20.0 \\
\hline \multirow[t]{4}{*}{ 3. Farming experience (years) } & Very Low $(\leq 3)$ & 2 & 2.0 \\
\hline & Low (4-6) & 7 & 7.0 \\
\hline & Medium (7-9) & 5 & 5.0 \\
\hline & $\operatorname{High}(\geq 10)$ & 86 & 86.0 \\
\hline \multirow[t]{4}{*}{ 4. Left farming (years) } & Very Low $(\leq 3)$ & 21 & 21.0 \\
\hline & Low (4-6) & 31 & 31.0 \\
\hline & Medium (7-9) & 31 & 31.0 \\
\hline & $\operatorname{High}(\geq 10)$ & 17 & 17.0 \\
\hline \multirow[t]{3}{*}{ 5. Family size } & Small $\leq 4$ members & 31 & 31.0 \\
\hline & Medium 5-8 members & 52 & 52.0 \\
\hline & Large $\geq 9$ members & 17 & 17.0 \\
\hline \multirow[t]{2}{*}{ 6. Family type } & Nuclear Family & 55 & 55.0 \\
\hline & Joint Family & 45 & 45.0 \\
\hline \multirow[t]{3}{*}{ 7. Dependent on the family } & $\leq 3$ members & 37 & 37.0 \\
\hline & 4-5 members & 31 & 31.0 \\
\hline & $\geq 6$ members & 32 & 32.0 \\
\hline \multirow[t]{2}{*}{ 8. Occupation } & Business & 58 & 58.0 \\
\hline & Service & 42 & 42.0 \\
\hline \multirow[t]{3}{*}{ 9. Land holdings } & Marginal and small farmers $(<2.5 \mathrm{ha})$ & 43 & 43.0 \\
\hline & Medium farmers (2.5-5.0 ha) & 43 & 43.0 \\
\hline & Big farmers (> 5.0) & 14 & 14.0 \\
\hline \multirow[t]{3}{*}{ 10. Livestock possession } & $\operatorname{Low}(\leq 1)$ & 72 & 72.0 \\
\hline & Medium (1-2) & 14 & 14.0 \\
\hline & $\operatorname{High}(\geq 2)$ & 14 & 14.0 \\
\hline \multirow[t]{6}{*}{ 11. Annual income (₹) } & $\leq 100,000$ & 41 & 41.0 \\
\hline & $100,001-200,000$ & 28 & 28.0 \\
\hline & $200,001-300,000$ & 13 & 13.0 \\
\hline & $300,001-400,000$ & 7 & 7.0 \\
\hline & $400,001-500,000$ & 1 & 1.0 \\
\hline & $\geq 500,001$ & 10 & 10.0 \\
\hline \multirow[t]{3}{*}{ 12. Social participation } & Low & 6 & 6.0 \\
\hline & Medium & 85 & 85.0 \\
\hline & High & 9 & 9.0 \\
\hline
\end{tabular}

\subsection{Relationship of the agricultural landholder's profile and factors to avoid agriculture} as a livelihood

The Kendall's tau-b correlation analysis conducted to identify the relationship between factors affecting to prevent farming as a livelihood and independent variables. An observation of Table 4 shows that ' $r$ ' computed between factors to avoid agriculture as a profession and age (0.589), education (0.330), farming experience (0.250), occupation 
Table 4 Correlation $(r)$ between profile of the agricultural landholders and factors to avoid agriculture as a profession $(n=100)$

\begin{tabular}{llc}
\hline Sr. no. & Variable & $\begin{array}{c}\text { Kendall's } \\
\text { tau-b' } \mathbf{r}^{\prime} \\
\text { value }\end{array}$ \\
\hline 1 & Age & $0.589^{* *}$ \\
2 & Education & $0.330^{* *}$ \\
3 & Farming experience & $0.250^{* *}$ \\
4 & Left the farming & $0.023^{\mathrm{NS}}$ \\
5 & Family size & $0.001^{\mathrm{NS}}$ \\
6 & Family type & $0.122^{\mathrm{NS}}$ \\
7 & Family dependence ratio & $0.008^{\mathrm{NS}}$ \\
8 & Occupation & $0.446^{* *}$ \\
9 & Landholding & $0.158^{*}$ \\
10 & Livestock possession & $0.207^{* *}$ \\
11 & Annual income & $0.236^{* *}$ \\
12 & Social participation & $0.150^{*}$ \\
\hline
\end{tabular}

**Significant at 0.01 level; *Significant at 0.05 level; NS non-significant

(0.446), livestock possession (0.207) and annual income ( -0.236$)$ was found to be significant at 0.01 level of significance. Thus, these variables of agricultural landholders were observed to be associated positively except annual income (negatively associated). The ' $r$ ' value computed for land holding (0.158) and social participation (0.150) with dependent variable was observed to be significant at 0.05 level probabilities. The remaining variables like left the farming, family size, family type, and family dependence ratio were found no significant relationship.

Logically, accumulation of better education, old age, higher farming experience among the agricultural landholder with a self-driven urge for a new adventure with the acceptance of new challenges to opt business and service as their livelihood, do result in avoiding agriculture as a profession. By definition, dependents are those who do not earn their living. The number of dependents in a family increases the number of mouths to be fed by the household head. This forced situation obviously, makes landholders under economic pressure to nurse these dependents. The dependents need fulfillment particularly during a crisis is very difficult. The results could be attributed to the fact that land holding, livestock possession and participation of individuals in formal and informal organizations or groups broadens one's sphere of interest and increases one's information concerns. Interaction opportunity helps to share ideas and refine their interpretation of the situation and other options for economic benefits. Also, exposure to varied persons heightens the aspirations of the individuals, a better understanding of the reality of the situation and finally helps in the estimation of the gap between what is and what ought to be. Additionally, economic crisis as they faced in the past forced them into opting better income source other than agriculture (Sarma 2004).

\subsection{The contribution of factors on agricultural landholders for avoiding farming as a livelihood}

A significant problem associated with studying the relationship between the groups of variables under study arises from the probability of choice of factors to be included in 
the model. To make sense, both from the theoretical and statistical point of view and avoid the element of subjectivity and other problems associated with specification and estimation in conventional analysis such as regression, a principal component analysis which transcends some of the issues is undertaken. This procedure may be useful for subsequent interpretation of the regression equation. The results of the principal component analysis are presented in Table 5 .

It was found that the first principal component contains well over 24 percent of variations of 12 variables. The four components contribute to over 65 percent of the total variation. The first component describes the relationship between factors to avoid farming as a profession with family factors meaningfully. Analysis of the second principal component clearly showed that personnel factors had strongly influenced to prevent farming in a positive direction. In the third component, social factors are contributing more, and an economic factor is affecting the positive trend in the fourth component.

\subsection{The relative importance of independent variables in explaining factors experienced by the agricultural landholders to avoid agriculture as a livelihood}

Regression analysis was carried out to establish the influence of some of the exogenous variables on factors to avoid farming as a profession. The stepwise regression was applied so that the specification bias of the model does not occur. The results are presented in Table 6. A scrutiny of the table shows that the fitted model is adequate in explaining the variation in the factors to avoid agriculture as a profession as indicated by a high and significant coefficient of multiple determinations 0.673 . In other words, $67.30 \%$ of the variation is explained by the factors included in the model. The standardized regression coefficient has been computed from the original 'b' coefficients so that they can be compared to the factors to assess the magnitude of the effect.

Table 5 Contribution of factors on agricultural landholders for avoiding farming as profession $(n=100)$

\begin{tabular}{|c|c|c|c|c|c|}
\hline \multirow[t]{2}{*}{ Sl. no. } & & \multicolumn{4}{|c|}{ Components } \\
\hline & & 1 & 2 & 3 & 4 \\
\hline & Eigen root & 2.909 & 2.181 & 1.470 & 1.253 \\
\hline & $\%$ Variation expressed & 24.239 & 18.173 & 12.249 & 10.445 \\
\hline & Cumulative variation expressed & 24.239 & 42.412 & 54.661 & 65.106 \\
\hline 1. & Age & 0.168 & 0.846 & -0.115 & 0.022 \\
\hline 2. & Education & -0.425 & 0.593 & -0.198 & 0.234 \\
\hline 3. & Farming experience & 0.320 & 0.646 & 0.143 & -0.057 \\
\hline 4. & years left the farming & -0.113 & 0.361 & -0.507 & -0.261 \\
\hline 5. & Family size & 0.847 & -0.037 & -0.258 & 0.237 \\
\hline 6. & Family type & 0.770 & 0.123 & -0.070 & 0.062 \\
\hline 7. & Family dependence ratio & 0.858 & -0.031 & -0.217 & 0.246 \\
\hline 8. & Occupation & -0.307 & 0.572 & 0.094 & 0.476 \\
\hline 9. & Land holding & -0.222 & 0.328 & -0.082 & -0.609 \\
\hline 10. & Livestock possession & 0.158 & 0.282 & 0.706 & 0.069 \\
\hline 11. & Annual income & -0.525 & -0.146 & 0.052 & 0.609 \\
\hline 12. & Social participation & 0.307 & 0.112 & 0.710 & -0.185 \\
\hline
\end{tabular}


Table 6 Stepwise regression analysis showing relative importance of profile factors in explaining to avoid agriculture as profession $(n=100)$

\begin{tabular}{llcclr}
\hline Sr. no. & Factors & \multicolumn{2}{c}{ Unstandardized coefficients } & $\begin{array}{l}\text { Standardized } \\
\text { coefficients } \\
\text { Beta }\end{array}$ & 't' value \\
\cline { 3 - 4 } & B & SE & & \\
\hline 1 & Family factors & 2.121 & 2.369 & 0.053 & $0.895^{\mathrm{NS}}$ \\
2 & Personal factors & 29.457 & 2.369 & 0.730 & $12.435^{* *}$ \\
3 & Social factors & 9.246 & 2.369 & 0.229 & $3.903^{* *}$ \\
4 & Economic factors & 11.737 & 2.369 & 0.291 & $4.955^{* *}$ \\
\hline
\end{tabular}

$R^{2}=0.673, R^{2}$ adj $=0.659, F=48.00$

**Significant at $0.01 \%$ level; NS non-significant

Table 7 Personal factors for avoiding agriculture as a profession $(n=100)$

\begin{tabular}{llll}
\hline Sr. no. & Statements & Mean & Rank \\
\hline 1. & Expecting a white-collar job & 3.28 & $\mathrm{VII}$ \\
2. & Poor interest in bringing children into farming profession & 3.74 & $\mathrm{II}$ \\
3. & Interested in work other than farming & 3.78 & $\mathrm{I}$ \\
4. & Preferred to settle in urban area & 3.39 & $\mathrm{~V}$ \\
5. & Desired to avoid drudgery-oriented work & 3.52 & $\mathrm{IV}$ \\
6. & Intended to avoid work in harsh weather condition & 3.54 & $\mathrm{III}$ \\
7. & Poor skill in farming & 2.89 & $\mathrm{IX}$ \\
8. & Health issues to avoid farming & 3.02 & $\mathrm{VIII}$ \\
9. & Old age restricting for farm work & 3.36 & $\mathrm{VI}$ \\
\hline
\end{tabular}

It could be observed from the table that the personal factors had the dominant effect (0.730) on avoiding agriculture as a profession, influencing in a positive direction. Followed by, economic factors $(0.291)$ and social factor (0.229) factors also influenced positively and significantly. However, family factors $(0.053)$ had non-significant and positive effects to avoid agriculture as an occupation in positive direction.

Comparison of beta values revealed that personal, economic and social factors had significant and highest effect on opting other than agriculture as a profession. Essentially, personal and financial factors enable the landholders to venture in innovative and risky enterprises and also it induces entrepreneurial behavior among farmers for acceptance of multiple complementary and supplementary enterprises/business combined adequately with off-farm income earning avenues.

\subsection{Personal factors for avoiding farming as a livelihood}

The information on the personal factors experienced by agricultural landholders is depicted in Table 7. After perceiving the difficulties in agriculture, the landholders initiated many alternatives to make their life stabilized and sustainable. The data in the table revealed that major personal factors faced by agricultural landholders to avoid agriculture as their livelihood were, interested in working other than farming (Rank I) followed by reduced interest in bringing children into the farming profession (Rank II) this could be due to the lack of support by the government. Intended to avoid work in harsh weather condition (Rank III), desired to avoid drudgery-oriented work (Rank IV), were 
significant personal factors. The probable reasons for this might be that in recent years farming is taking place in small scale with low per capita land availability, low income, and poor interest in farming. The results are in accordance with Prasad et al. (2006), Radhakrishnan and Andrade (2012) and Manoranjitham et al. (2010).

\subsection{Social factors for avoiding farming as a livelihood}

It could be observed from Table 8 about the social factors responsible for avoiding agriculture as a livelihood. The majority of respondents in the study sites expressed that they would like to offer high social status to children by providing higher education (Rank I). They did not find a life partner as girls refused to marry rural youth (Rank II), surprisingly present generation girls are declined to marry a farmer as their life partner as they live in the village and with low social status. Family members did not support to continue farming (Rank III), even there is a lack of encouragement from the family members, and this leads to avoid farming. Being farmer, not recognized by society (Rank IV), were significant social factors. The reasons were evidence that people do agriculture that is not capable of other profession and government failed to provide respectable social status to the farmer and farm families. The results are in accordance with Prasad et al. (2006), Radhakrishnan and Andrade (2012) and Manoranjitham et al. (2010).

\subsection{Economic factors for avoiding agriculture as a livelihood}

In recent day's farmers facing a lot of problems in their farming, it may be a climatic aberration, high input cost, the low market price for their produce, etc., and their situational conditions are restricting them to take up any adjustments in their farming due to internal as well as external factors. With this background, efforts have been made to know the economic factors experienced by landholders to avoid agriculture as their livelihood. Ranks have been given based on the responses. From Table 9 it can be revealed that it has high risk because as it is nature-dependent profession ranked first followed by the high cost of production (Rank II); hybrid seeds were costlier (Rank III); fertilizers cost was high (Rank IV), were the principal economic factors are influencing to avoid farming.

\subsection{Psychological factors for avoiding farming as a livelihood}

The data presented in Table 10 revealed that negative attitude toward the agriculture as a profession (Rank I), followed by lost interest in farming (Rank II), and insecure toward agriculture (Rank III) and reduced confidence in the adoption of scientific farm technologies (Rank IV) were the primary psychological factors. It was observed that psychological factors play a significant role in once livelihood option. Here the majority of

Table 8 Social factors for avoiding agriculture as a profession $(n=100)$

\begin{tabular}{llll}
\hline Sr. no. & Statements & Mean & Rank \\
\hline 1. & Being farmer, not recognized by society & 2.90 & $\mathrm{IV}$ \\
2. & did not find a life partner as girls refused to marry a rural youth & 3.23 & $\mathrm{II}$ \\
3. & People can do farming who are incapable of other work & 2.88 & $\mathrm{~V}$ \\
4. & High social status to children by offering higher education & 4.19 & $\mathrm{I}$ \\
5. & Family members did not support to continue farming & 2.92 & $\mathrm{II}$ \\
6. & Son wanted to take rest and enjoy life & 3.23 & II \\
\hline
\end{tabular}


Table 9 Economic factors for avoiding farming as a profession $(n=100)$

\begin{tabular}{llll}
\hline Sr. no. & Statements & Mean & Rank \\
\hline 1. & The productivity of farm was very law & 3.65 & $\mathrm{VI}$ \\
2. & High cost of production & 4.03 & $\mathrm{II}$ \\
3. & High risk because as it is nature-dependent profession & 4.11 & $\mathrm{I}$ \\
4. & Cost of fertilizers was high & 3.79 & $\mathrm{IV}$ \\
5. & Agrochemicals cost was high & 3.72 & $\mathrm{~V}$ \\
6. & Hybrid seeds were costlier & 3.88 & $\mathrm{III}$ \\
7. & Insufficient funds for farming & 3.56 & $\mathrm{VII}$ \\
8. & Difficulties to access agricultural loan with the reasonable interest & 3.44 & $\mathrm{IX}$ \\
& $\quad$ rate & & \\
9. & Unfriendly crop insurance system & 3.46 & $\mathrm{VIII}$ \\
\hline
\end{tabular}

Table 10 Psychological factors for avoiding farming as a profession $(n=100)$

\begin{tabular}{llll}
\hline Sr. no. & Statements & Mean & Rank \\
\hline 1. & Poor risk-bearing capacity in farming & 3.15 & IX \\
2. & Poor knowledge of farming & 3.09 & X \\
3. & Lost interest in farming & 3.54 & II \\
4. & Negative attitude toward the agriculture as a profession & 3.56 & $\mathrm{I}$ \\
5. & Poor marketing intelligence to sell farm products & 3.45 & $\mathrm{IV}$ \\
6. & Poor confidence in adoption of scientific farm technologies & 3.38 & $\mathrm{VI}$ \\
7. & Not-confident to do farming & 3.32 & $\mathrm{VIII}$ \\
8. & Poor innovativeness in farming & 3.35 & $\mathrm{VII}$ \\
9. & Lack of agricultural wisdom & 3.39 & $\mathrm{~V}$ \\
10. & Insecure toward farming & 3.50 & $\mathrm{III}$ \\
\hline
\end{tabular}

the respondents were lost interest and have less confidence to take agriculture as their profession, which may due to the negative experience of previous years in farming activities. The results are in accordance with Radhakrishnan and Andrade (2012) and Manoranjitham et al. (2010).

\subsection{Market-related factors for avoiding farming as a livelihood}

The data in Table 11 revealed that market-related factors experienced by the agricultural landholders to avoid agriculture as their occupation was, unfair return due to unorganized market system (Rank I) followed by lack of policy to decide price by the producer (Rank II), inappropriate market facility for agricultural products (Rank III), dominance of intermediary in agromarketing (Rank IV), were the primary market-related factors. Other reasons are like the higher cost of the agricultural inputs, non-availability of timely inputs, low price for the produce in the market, non-availability of labors in the village. The government should bring a workable marketing model for the benefit of farmers and farm families. Chandrasekhar and Ghosh (2010) argued that increasing food prices from 2006 onward have benefited the middlemen and not the farmers. Patnaik (2006) and Mishra (2008) discussed the inequalities and interlinked transactions in agrarian markets. 
Table 11 Market-related factors for avoiding agriculture as a profession $(n=100)$

\begin{tabular}{llll}
\hline Sr. no. & Statements & Mean & Rank \\
\hline 1. & Inappropriate market facility for agricultural products & 4.14 & $\mathrm{III}$ \\
2. & Price fluctuation in farm products made to quit farming & 3.96 & $\mathrm{VI}$ \\
3. & Lack of system to decide price by the producer & 4.44 & $\mathrm{II}$ \\
4. & Unfair return due to unorganized market system & 4.45 & $\mathrm{I}$ \\
5. & Costly transport facilities to sell my farm produce & 3.85 & $\mathrm{VIII}$ \\
6. & Lack of transport facility & 3.58 & $\mathrm{X}$ \\
7. & Value addition units were not in village & 3.76 & $\mathrm{IX}$ \\
8. & Dominance of intermediary in agromarketing & 4.04 & $\mathrm{IV}$ \\
9. & No workable contract marketing system & 3.92 & $\mathrm{VII}$ \\
10. & Unfavorable farm trade policies of government & 4.03 & $\mathrm{~V}$ \\
\hline
\end{tabular}

Table 12 Labor-related factors for avoiding agriculture as a profession $(n=100)$

\begin{tabular}{llll}
\hline Sr. no. & Statements & Mean & Rank \\
\hline 1. & Unavailability of skilled labors & 4.31 & I \\
2. & Dominance of labor due to industrialization & 4.28 & II \\
3. & MGNREGA created problem in availability of labor & 4.00 & $\mathrm{~V}$ \\
4. & Laborers avoiding drudgery-oriented farm work & 4.10 & $\mathrm{III}$ \\
5. & Unavailability of farm labors as and when needed & 4.01 & $\mathrm{IV}$ \\
6. & Village labors want to do construction work than farm labor & 3.89 & $\mathrm{VI}$ \\
7. & work & 3.66 & $\mathrm{VII}$ \\
\hline
\end{tabular}

\subsection{Labor-related factors for avoiding farming as a livelihood}

It could be observed from Table 12 that labor-related factors were another reason to avoid agriculture as a profession. The majority of the labors were migrated from village to nearby cities. Most of them relocated to Ahmadabad city because Ahmadabad is the city where they can get the job at a faster rate and get a good salary by joining wage work in the factories and other places. Majority of the migrated people were working in the factory followed by garments, engaged in real estate business and as a carpenter. This shows that marginal and small farm families were more prone to avoid farming profession than big farmers. Some of the reasons were like unavailability of skilled labors (Rank I) followed by the dominance of labor due to industrialization (Rank II), laborers avoiding drudgery-oriented farm work (Rank III) and unavailability of farm labors as and when needed (Rank IV) which were the major labor-related factors.

\subsection{Situational factors for avoiding farming as a livelihood}

The information on the situational factors experienced by agricultural landholders is depicted in Table 13. The data in the table revealed that lack of support service in agriculture (Rank I) followed by inadequate storage facility to store agricultural products (Rank II) this could be due to the lack of support by the government. Erratic weather conditions lead to leaving farming (Rank III), and high competition from large farmers (Rank IV) were significant situational factors. The probable reasons for 
Table 13 Situational factors for avoiding agriculture as a profession $(n=100)$

\begin{tabular}{llll}
\hline Sr. no. & Statements & Mean & Rank \\
\hline 1. & Lack of irrigation facility for farming & 3.47 & $\mathrm{X}$ \\
2. & Cultural norms restricted female to work in farming & 3.59 & $\mathrm{VII}$ \\
3. & Poor construction of canals in village & 3.53 & $\mathrm{VIII}$ \\
4. & Very low-level of the water table restricted to go for multiple cropping & 3.52 & $\mathrm{IX}$ \\
5. & Unavailability of low-cost irrigation systems in village & 3.60 & $\mathrm{VI}$ \\
6. & Tube well irrigation was impossible due to poor water quality & 3.46 & $\mathrm{XI}$ \\
7. & Fragmentation of land into unconventional size leads to poor mechaniza- \\
& $\quad$ tion in farming & 3.67 & $\mathrm{~V}$ \\
8. & Scarce of electricity & 3.31 & $\mathrm{XII}$ \\
9. & High competition from large farmers & 3.81 & $\mathrm{IV}$ \\
10. & Soil degradation leads to quitting farming & 3.47 & $\mathrm{X}$ \\
11. & Erratic weather conditions lead to leaving farming & 3.94 & $\mathrm{III}$ \\
12. & Inadequate storage facility to store agricultural products & 3.97 & $\mathrm{II}$ \\
13. & Lack of support service in agriculture & 3.99 & $\mathrm{I}$ \\
14. & Sold land to builders due to high rate per land & 3.12 & $\mathrm{XIII}$
\end{tabular}

Table 14 Next-generation related factors for avoiding farming as a profession $(n=100)$

\begin{tabular}{lllc}
\hline Sr. no. & Statements & Mean & Rank \\
\hline 1. & Children had poor interest in farming & 4.27 & II \\
2. & Educated children want to join other than farming professions & 4.34 & I \\
3. & Son wants to settle in an urban area after taking higher education & 4.03 & III \\
4. & Poor facility of urban amenities in my village restricted children to settle & 3.85 & V \\
& $\quad$ in the rural area & 3.96 & IV \\
5. & Migrated children do not want to leave urban area & & \\
\hline
\end{tabular}

this might be they expressed that it is highly challenging to make a profit by occupying agriculture as a profession under the unusual climatic conditions in their locality. Hence, they migrated to cities and towns to earn and lead the life in a better way. Farming is not only gambling with climatic factors but also internal and external factors. These situational issues need to be addressed by the government. The results are in line with the (Mishra 2006; Sadanandan 2014).

\subsection{Next-generation related factors for avoiding farming as a livelihood}

Agriculture is counted in the category of unorganized sector, so farmer's income is not fixed. Hence they are living an insecure and underprivileged life and with full uncertainty in their earnings. The farm families are one of the most exploited and oppressed classes in the rural hierarchy. Hence we could observe that future generation is avoiding agriculture as their profession. Some of the reasons presented in Table 14 were educated children want to join other than farming professions (Rank I) followed by children had poor interest in farming (Rank II), son wants to settle in an urban area after taking higher education (Rank III), and migrated children do not want to leave metropolitan area (Rank IV), the main reasons to avoid farming profession. 


\subsection{Landholders' suggestions to adopt farming as a livelihood}

The suggestions for adopting agriculture as a profession, as reported by the respondents, were analyzed using the mean score, and the results are presented in Table 15. Results show that out of the 22 suggestions given by the respondents, 'Government should offer pension to the well-experienced farmers during their old age' was ranked first. It will attract much young generation to practice farming as a profession, as they get benefit during a later stage of life as like government servant. 'Farmer'-friendly storage facility should be provided to support farmers to earn the high cost of farm products' was ranked second as they may benefit from better price during the offseason of the crop. The respondents ranked the 'In government recruitment, special reservation should be given to farm families' as the third suggestion as there is reservation system for caste, and farmers seek that their next generation should get the benefit of reservation in the government recruitment process. The fourth rank was given to 'farmer'-friendly crop insurance system should be implemented' as agriculture is gambling with climatic and price fluctuation, farmers are facing a crisis. Insurance has to be extended to all crops this was probably due to price

Table 15 Agricultural landholders' suggestions to adopt farming as a profession $(n=100)$

\begin{tabular}{|c|c|c|c|}
\hline Sr. no. & Farmers suggestions & Mean score & Rank \\
\hline 1 & $\begin{array}{l}\text { The government should offer pension to the well-experienced farmers during } \\
\text { their old age }\end{array}$ & 3.92 & I \\
\hline 2 & $\begin{array}{l}\text { Workable farmer-friendly storage facility should be provided to support farmers to } \\
\text { earn the high cost of farm products }\end{array}$ & 3.74 & $\|$ \\
\hline 3 & In government recruitment, special reservation should be given to farm families & 3.73 & III \\
\hline 4 & Workable farmer-friendly crop insurance system should be implemented & 3.72 & IV \\
\hline 5 & $\begin{array}{l}\text { The policy should be developed to attract agricultural graduates to adopt farming } \\
\text { than going for a job }\end{array}$ & 3.71 & V \\
\hline 6 & $\begin{array}{l}\text { Practical and employability generating higher agricultural education should be } \\
\text { implemented }\end{array}$ & 3.69 & VI \\
\hline 7 & $\begin{array}{l}\text { Knowledge of farming should be compulsory from school level to develop posi- } \\
\text { tive attitude in youths }\end{array}$ & 3.68 & VII \\
\hline 8 & $\begin{array}{l}\text { The policy should be developed to offer job during off seasons to the farmers in a } \\
\text { rural area by establishing small-scale industries }\end{array}$ & 3.67 & VIII \\
\hline 9 & $\begin{array}{l}\text { The government should provide urban amenities in rural areas to attract youth } \\
\text { toward agriculture }\end{array}$ & 3.66 & IX \\
\hline 10 & There should be special policy for small and marginal farmers & 3.65 & $x$ \\
\hline 11 & Government intervention to cover more area under irrigation & 3.64 & $X I$ \\
\hline 12 & $\begin{array}{l}\text { The encouraging policy should be developed to accelerate youth involvement in } \\
\text { farming }\end{array}$ & 3.63 & $X I I$ \\
\hline 13 & $\begin{array}{l}\text { Low-cost implements should be developed for different size of farm holders to } \\
\text { reduce labor problems }\end{array}$ & 3.61 & $\mathrm{XIII}$ \\
\hline 14 & Adequate and timely supply of electricity & 3.60 & XIV \\
\hline 15 & Quality of Channel should be improved & 3.59 & $X V$ \\
\hline 16 & Assured marketing facilities for the agricultural products & 3.58 & $X \mathrm{VI}$ \\
\hline 17 & $\begin{array}{l}\text { Government should have control over input suppliers to make timely availability } \\
\text { of agricultural inputs }\end{array}$ & 3.57 & $X V I I$ \\
\hline 18 & Credit facilities should be farmer'friendly & 3.55 & $X \mathrm{X} I I I$ \\
\hline 19 & Channel irrigation water should be made available as and when needed & 3.53 & XIX \\
\hline 20 & Workable easy policy of farm product export should be implemented & 3.49 & $X X$ \\
\hline 21 & $\begin{array}{l}\text { Workable farming system models for different types of areas and farmers should } \\
\text { be developed }\end{array}$ & 3.45 & $X X I$ \\
\hline 22 & More encouragement should be given to agrotourism & 3.22 & $X X I I$ \\
\hline
\end{tabular}


fluctuation in the market and contingency plan may be worked out by the researchers to minimize the effect of climate change and other human intervention factors. The fifth rank was given to 'policy should be developed to attract agricultural graduates to adopt farming than searching for the job. These are the essential suggestions expressed by respondents based on their experience in farming over an extended period. Development departments should think and reorient about all these suggestions of farmers to fulfill their needs to attract young generation toward agriculture and to adopt farming as their livelihood.

\section{Conclusion}

The green revolution strategy which brought a phenomenal growth in the farming sector and improved the financial conditions of the farming community during the 1970s and 1980s seems to be growing dim with time. Indian farming, the most significant body of surviving marginal and small farmers in the world, today faces a crisis of extinction. Twothirds of India makes its living from the land. The earth is the most generous employer in this country of a billion that has farmed this area for more than 5000 years. Though, as farming is delinked from the earth, the soil, the biodiversity, the climate and linked to global companies and global markets, and the generosity of the earth is replaced by the greed of companies, the viability of small farmers and small farms are destroyed. The average size of operational land holding has declined to 1.15 ha. in 2010-2011 as likened to 1.23 in 2005-2006. The average land holding of marginal and small farmers in India is too low (less than 1 ha.) that they cannot generate adequate employment and income for their livelihood and are forced to live below poverty line. The situation is likely to get worse because of the increasing pressure of population on land, scare natural resources and the limited scope of increasing additional production through traditional farming. One of the principal consequences of this agrarian crisis has been that the marginal and small farmers, who find it increasingly crisis to sustain on agriculture, are getting pushed out from the agricultural sector. The trends for agriculture show that $14 \%$ woman and $3.2 \%$ of farmers since 2001 have abandoned farming. This extrapolates to over 8.6 million people. Thousands of tenant farmers are reported to have committed suicide in the last few years.

It is argued that the consequence of the farming crisis in India is rapid and probable to hit all the other sectors and the counties' economy by several means. In specific, it has adverse effects on food supply, prices, cost of living, health, nutrition, poverty, employment, labor market, land loss from farming and foreign exchange earnings. In sum, it revealed that the agricultural crisis would be affecting a majority of the population in India and the economy as a whole in a long way. However, it can be argued that the crisis in farming is a crisis of the country as a whole. The only remedy to the crisis is to do all that is possible to make farming a profitable sector and attract the youth to continue the crop production activities. As an effort toward this direction, the government should augment its investment and expenditure in the farm sector. Investment in agriculture and its allied areas, including irrigation, electricity, transport, communication, rural market, rural infrastructure, storage, processing, and farm research, should be drastically increased, and the government should aim at the integrated development of the rural areas. The solution to the problem is not in a few "packages," but drastic changes in the present economic policies related to agriculture need to be done. Other sector's growth and development must not be at the cost of agriculture (Shah et al. 2009). All agrarians, 
agricultural laborers, societies, government, and farmers' organizations should work collectively to revive agriculture and "Save India from Agriculture Crisis."

\section{Recommendations of the day}

One of the challenges India is facing nowadays is achieving inclusive growth and proper strategy to revive Indian agriculture. The farm population has been waiting patiently year after year for a 'new deal' for agriculture. Doubling agricultural growth is the immediate challenge. However, the package of the recent strategy and efforts seems to be incremental, rather than a holistic for reviving agriculture. The supply and demand side constraints have to be removed to raise growth. The support systems have to be tuned to improve productivity and incomes of farmers with emphasis on small and marginal farmers and dry-land areas.

The suggestions given by rural landholders to attract young people toward farming are: Government should offer pension to the well-experienced farmers during their old age; practical and employability generating higher agricultural education should be implemented; in government recruitment, special reservation should be given to farm families; and channel irrigation water should be made available as and when needed are required to be addressed by concerned departments.

Authors' contributions

Vinaya is a principle investigator and other authors are equally contributed during the research and paper writing.

Acknowledgements

We would like to express our special thanks to Anand Agricultural University, Anand, for the financial support.

Competing interests

The authors declare that they have no competing interests.

Availability of data and materials

Not applicable.

Funding

Anand Agricultural University.

\section{Publisher's Note}

Springer Nature remains neutral with regard to jurisdictional claims in published maps and institutional affiliations.

Received: 9 October 2018 Accepted: 25 February 2019

Published online: 09 March 2019

\section{References}

Accidental deaths and Suicides in India (2015) National Crime Records Bureau. https://www.iitgn.ac.in/pdf/ news/2017/02/TOI-08-02-2017.pdf. Accessed 21 May 2017

Agerbo E, Gunnell D, Bonde JP, Bo MP (2007) Nordentoft M (2007) Suicide and occupation: the impact of socio-economic, demographic and psychiatric differences. Psychol Med 37:1131-1140

Agriculture Census (2011) All India report on number and area of operational holdings. http://agcensus.nic.in/docum ent/agcensus2010/completereport.pdf. Accessed 01 Mar 2017

Business Standard (2015) Smaller farms, lack of jobs push farmers to move to cities. http://www.business-standard. com/article/economy-policy/smaller-farms-lack-of-jobs-push-farmers-to-move-to-cities-115120600006_1.html., Accessed 2 Mar 2017

Chandrasekhar CP, Ghosh J (2010) Controlling food prices. Macroscan (http://www.macroscan.org. Accessed 21 Sep 2012 Citizens'Report (1998) Gathering agrarian crisis: farmers' suicides in Warangal, Andhra Pradesh (Unpublished)

Deshmukh N (2015) 1 lakh farmers quit agriculture in 5 years in Maharashtra. The Times of India, http://timesofindia.india times.com/india/1-lakh-farmers-quit-agriculture-in-5-years-in-Maharashtra/articleshow/48718024.cms. Accessed 01 Mar 2017

Dominic M (2017) Factors associated with the farmer suicide crisis in India. J Epidemiol Glob Health 2017(6):217-227 Food and Agricultural Organization (FAO) (2012) Realizing the potential of agricultural innovation in family farming. http://www.fao.org/uploads/media/OEKR_folder_webversion.pdf. Accessed 26 Feb 2017

Food and Agricultural Organization (FAO) (2014a) International Year of family farming (IYFF). http://www.fao.org/famil y-farming-2014/home/what-is-family-farming/en/. Accessed 25 Feb 2017 
Food and Agricultural Organization (FAO) (2014b) Forum on communication for development and community media for family farming, \{http://www.fao.org/3/a-as888e.pdf. Accessed 01 March 2017

Gill A, Lakhwinder S (2006) 'Farmers' suicides and response of public policy evidence, diagnosis and alternatives from Punjab. Economic and Political Weekly, June 30

Indian Economic Survey 2015-2016

Krishnan U (2015) Why 75\% of Indian farmers want to leave farming? https://www.quora.com/Why-75-of-Indian-farme rs-want-to-leave-farming. Accessed 20 Feb 2017

Krishnaswamy N (2015) What happens when most of the Indian farmers quit farming? https://www.quora.com/Whathappens-when-most-of-Indian-farmers-quit-farming. Accessed 01 Mar 2017

Manoranjitham SD, Rajkumar AP, Thangadurai P, Prasad J, Jayakaran R (2010) Jacob KS (2010) Risk factors for suicide in rura south India. Br J Psychiatry 196:26-30

Milner A, Spittal MJ, Pirkis J, LaMontagne AD (2013) Suicide by occupation: systematic review and meta-analysis. Br J Psychiatry 203:409-416

Mishra S (2006) Suicide of farmers in Maharashtra. http://www.igidr.ac.in/conf/suicide/FinalReport_SFM_IGIDR_26Jan 06.pdf. Accessed 25 July 2015

Mishra DK (2008) Structural inequalities and interlinked transactions in agrarian markets: results of a field survey. In: Bhaumik SK (ed) Reforming Indian Agriculture. Towards employment generation and poverty reduction. Sage, New Delhi, pp 231-268

Mitra S, Shroff S (2007)'Farmers'suicides in Maharashtra. Economic and Political Weekly, December 8

Nagaraj K (2015) Farmers'suicides in India: magnitudes, trends and spatial patterns. http://www.macroscan.org/anl/ mar08/pdf/farmers_suicides.pdf. Accessed 01 June 2015

Parthasarathy G, Shameem (1998) Suicides of cotton farmers in Andhra Pradesh an exploratory study. Economic and Political Weekly, March 28

Patel V, Ramasundarahettige C, Vijayakumar L, Thakur J, Gajalakshmi V, Gururaj G et al (2012) Suicide mortality in India: a nationally representative survey. Lancet 379:2343-2351

Patnaik U (2006) Unleashing the market: global capitalism, deflation and agrarian crisis in developing countries. In: John $\mathrm{M}$, et al (eds) Contested transformations: changing economies and identities in contemporary India, Tulika, Delhi

Prasad J, Abraham VJ, Minz S, Abraham S, Joseph A, Muliyil JP et al (2006) Rates and factors associated with suicide I Kaniyambadi Block, Tamil Nadu, South India, 2000-2002. Int J Soc Psychiatry 52:65-71

Radhakrishnan R, Andrade C (2012) Suicide: an Indian perspective. Indian J Psychiatry 54:304-319

Sadanandan A (2014) Political economy of suicide: financial reforms, credit crunches and farmer suicides in India. J Dev Areas. http://muse.jhu.edu/login?auth=0\&type=summary\&url=/journals/journal_of_developing_areas/ v048/48.4.sadanandan.html. Accessed 08 May 2015

Sainath P (2013) Over 2000 fewer farmers every day MAY 02, The Hindu. http://www.thehindu.com/opinion/columns/ sainath/over-2000-fewer-farmers-everyday/article4674190.ece. Accessed 15 May 2018

Sarma EAS (2004) Is rural economy breaking down? Farmers'suicides in Andhra Pradesh. Econ Polit Wkly, July 10

Shah T, Gulati A, Hemant P, Shreedha G, Jain RG (2009) Secret of Gujarat's Agrarian Miracle after 2000. Econ Polit Wkly 46(52):45-55

Sidhu RS, Sukhpal Singh, Bhullar AS (2011) Farmers' suicides in punjab: a census survey of the two most affected districts. Economic and Political Weekly, June 25

Singh S (2004) Crisis and diversification in Punjab agriculture role of state and agribusiness. Economic and Political Weekly, December 25

Singh K (2008) Water table behaviour in Punjab: issues and policy options, IWMI-TATA water policy research program. In: Proceedings of the 7th annual partners' meet: managing water in the face of growing scarcity, inequity and declining returns: exploring fresh approaches, vol I, ICRISAT Campus, Patancheru, Hyderabad, pp 331-357

Singh K (2009) Agrarian Crisis in Punjab: High Indebtedness, Low Returns and Farmers Suicides. In: D. Narasimha Reddy and Srijit Mishra (eds.), Agrarian Crisis in India. Oxford University Press, Oxford, pp 261-84

Sood J (2014) India's deepening farm crisis: 76\% farmers want to give up farming, Down To Earth, \{http://www.downt oearth.org.in/news/Indias-deepening-farm-crisis-76-farmers-want-to-give-up-farming-shows-study-43728. Accessed 25 Feb 2017

Vaidyanathan A (2006) 'Farmers'suicides and the agrarian crisis, Economic and Political Weekly, September 23

Vyas VS (2004) Agrarian distress: strategies to protect vulnerable sections. Economic \& Political Weekly, December 25

\section{Submit your manuscript to a SpringerOpen ${ }^{\circ}$ journal and benefit from:}

- Convenient online submission

- Rigorous peer review

- Open access: articles freely available online

- High visibility within the field

Retaining the copyright to your article

Submit your next manuscript at $\gg$ springeropen.com 